\title{
Domestic politics, news media and humanitarian intervention: why France and Germany diverged over Libya
}

Citation for published version (APA):

Bucher, J., Engel, L., Harfensteller, S., \& Dijkstra, H. (2013). Domestic politics, news media and humanitarian intervention: why France and Germany diverged over Libya. European Security, 22(4), 524539. https://doi.org/10.1080/09662839.2013.766597

Document status and date:

Published: 01/01/2013

DOI:

10.1080/09662839.2013.766597

Document Version:

Accepted author manuscript (Peer reviewed / editorial board version)

Document license:

Unspecified

Please check the document version of this publication:

- A submitted manuscript is the version of the article upon submission and before peer-review. There can be important differences between the submitted version and the official published version of record.

People interested in the research are advised to contact the author for the final version of the publication, or visit the DOI to the publisher's website.

- The final author version and the galley proof are versions of the publication after peer review.

- The final published version features the final layout of the paper including the volume, issue and page numbers.

Link to publication

\footnotetext{
General rights rights.

- You may freely distribute the URL identifying the publication in the public portal. please follow below link for the End User Agreement:

www.umlib.nl/taverne-license

Take down policy

If you believe that this document breaches copyright please contact us at:

repository@maastrichtuniversity.nl

providing details and we will investigate your claim.
}

Copyright and moral rights for the publications made accessible in the public portal are retained by the authors and/or other copyright owners and it is a condition of accessing publications that users recognise and abide by the legal requirements associated with these

- Users may download and print one copy of any publication from the public portal for the purpose of private study or research.

- You may not further distribute the material or use it for any profit-making activity or commercial gain

If the publication is distributed under the terms of Article $25 \mathrm{fa}$ of the Dutch Copyright Act, indicated by the "Taverne" license above, 


\title{
Domestic Politics, News Media and Humanitarian Intervention: Why France and Germany Diverged over Libya
}

\author{
Jessica Bucher, Lena Engel, Stephanie Harfensteller and Hylke Dijkstra
}

Accepted version of an article published in European Security 22(4), 2013, pp. 524-539

DOI: $10.1080 / 09662839.2013 .766597$

\begin{abstract}
The European Union member states split over the military intervention in Libya with France, Germany and the United Kingdom voting differently in the United Nations Security Council. This article compares news media in France and Germany to better understand the foreign policy decisions of these key actors. Using a newspaper analysis of 334 articles, it shows that the German domestic debate started very late and was much less stable than the French debate. This supports arguments that Germany's decision-making was erratic. The analysis, however, also shows that the German debate was comprehensive and included an extensive discussion of the legitimacy of intervention. This fits in well with the traditional reluctance of German foreign policy elites to support military action.
\end{abstract}

\section{KEYWORDS}

France, Germany, humanitarian intervention, Libya, responsibility to protect

\section{INTRODUCTION}

The humanitarian intervention in Libya in 2011 was not Europe's finest hour. Apart from the lack of adequate military capabilities and the reliance on the United States for precision-guided missiles, aerial refuelling capabilities as well as intelligence, surveillance and reconnaissance (Gates 2011; Barry 2011; Hallams and Schreer 2012; Daalder and Stavridis 2012), Europe also lacked internal political consensus (cf. Hill 1993; Toje 2008). Whereas France and the United Kingdom played leadership roles in the United Nations (UN) Security Council, Germany joined the emerging powers by abstaining from voting on Resolution 1973. This naturally led to split in the European Union (EU) with pro- and contra-interventionist camps. ${ }^{1}$ As a result, the EU became sidelined in spite of having actively promoted its neighbourhood policy at least since the mid-1990s.

To explain why European states made different foreign policy choices over the humanitarian intervention in Libya, this article investigates news media in the most-different cases France and Germany. It analyses the content of 334 newspaper articles in the run up to the intervention to see whether there are differences that may help to explain foreign policy choices. The findings are threefold. First, Libya became topic of debate much later in Germany than in France. Since events

1 While Germany and Poland displayed clear opposition to the Libyan intervention, only a few EU member states (Belgium, Denmark, France, Italy and United Kingdom, see Benitez 2011) actually participated in military combat operations. Some other member states militarily supported the arms embargo with their navy and air force. 
moved very quickly, it is well conceivable that the German elites were caught by surprise and had difficulty formulating policy responses. This is supported by the second finding that the arguments in favour and against intervention changed in the German newspapers from week-to-week. In France, on the contrary, newspapers increasingly presented pro-intervention arguments. That having been said, the article thirdly shows that there was much more debate about the legitimacy of the intervention in Germany. This points at continuity in the German foreign policy tradition.

The article starts by discussing the importance of domestic politics, public opinion and news media for the formulation of foreign policy and particularly humanitarian intervention. It then gives an overview of French and German foreign policy regarding intervention and the Southern Mediterranean. In terms of the empirical analysis, this article provides first the overall overview in terms of numbers of articles per week, the contents of the articles and the sorts of arguments made in the newspaper articles. It subsequently compares the various arguments made in both the French and German press in the weeks leading up to the vote on Resolution 1973. The article concludes by discussing the implications of these findings.

\section{DOMESTIC POLITICS, PUBLIC OPINION AND NEWS MEDIA}

How can we explain that two units with roughly the same capabilities react differently to an event in international politics? To provide an answer to this puzzle, one needs to go beyond the systemic theories of international relations and turn to domestic politics (e.g. Rosenau 1967; Allison 1971; Putnam 1988; Milner 1997; Moravcsik 1997). The argument is that foreign policy decision-makers are not only after maintaining the relative position of the state in the international system, but are also subject to domestic inputs coming from the electorate, legislature, bureaucratic politics, interests groups, etcetera. Such inputs can positively inform foreign policy (Jentleson 1992; Jentleson and Britton 1998; Eichenberg 2005) or constrain decision-makers leading to "a suboptimal foreign policy" (Fearon 1998: 289) from the systemic perspective.

Wolfgang Müller and Kaare Strom (1999) have suggested that politicians often face tradeoffs between policy, office or votes. As a result politicians may sacrifice their individual policy preferences or what they consider is best for the country over re-election. Public opinion is, in this respect, important for politicians as it affects their future prospects. This counts in the area of foreign policy as well. James Rosenau (1961), for example, argued more than fifty years ago that if politicians completely ignore public opinion on foreign policy, they would bare electoral costs. His argument was confirmed in the case of Vietnam (e.g. Beach 2012). In more recent years, various other scholars have also established a relationship between public opinion and foreign policy (e.g. Risse-Kappen 1991; Holsti 1992, 1996; Powlick and Katz 1998; Sobel 2001; Stimson 2004; Hildebrandt et al. 2012). ${ }^{2}$

Public opinion becomes particularly important if there exists no clearly identifiable national interest (e.g. Baum 2004; Davis 2012). During much of the Cold War, interests were relatively straightforward in the context of bipolarity. As a result, the preferences of the public and elite decision-makers were much of the time in line, despite perhaps debate on the means to reach those ends. This made the two-level games (Putnam 1988) relatively easy for politicians. In the post-Cold War period, national interest is much more difficult to identify with the result that cleavages may occur between the public and the decision-makers (e.g. isolationist and interventionist). In such a situation, two-level games are much more tricky and elected politicians need to listen carefully to the wishes of their constituencies.

Humanitarian interventions constitute, in this respect, the most difficult balancing act for politicians (Hildebrandt et al. 2012). ${ }^{3}$ They do not serve the narrowest definition of national interest

2 Needless to say, ever since Gabriel Almond (1950) and Walter Lippmann (1955) various scholars also have questioned the link between public opinion and foreign policy. Their argument is that voters do not really care about foreign policy, that decision-makers tend to look after the national interest, and that foreign policy is typically the domain réservé of the head of state or government.

3 Hildebrandt et al. (2012) provide a very useful literature discussion on public opinion and humanitarian intervention. 
but do require significant national resources. ${ }^{4}$ Politicians are, on the one hand, part of international elites that have accepted international norms such as the Responsibility to Protect (R2P). They face, on the other hand, voters who are often sceptical (Jentleson 1992; Jentleson and Britton 1998). Commenting on the situation in the United States, Timothy Hildebrandt et al. (2012: 8) note that "[w] hen it comes to humanitarian intervention in particular, popular wisdom seems to be that the American public has little tolerance for it". Voters are not willing to put lives and financial means on the line for something that has little to do with narrow national interests (Kull 1995; Jentleson 1992; Jentleson and Britton 1998; Eichenberg 2005).

The argument is not necessarily that humanitarian intervention is always blocked by public opinion, but that politicians, who face re-election, take notice of voters' preferences. Humanitarian interventions can, of course, also yield positive payoffs for politicians. Voters do care about human rights and if an international intervention is effective, politicians may reap the benefits. Yet the payoffs are relatively small and the risks significant (Donnelly 1993). Hildebrandt et al. (2012: 8) note, in this respect, "[ $\mathrm{t}]$ he public is more likely to punish ... political elites for a military campaign gone awry than they are to reward elected officials for a military success. Arguably, the stakes are even higher when the military campaign is waged not in pursuit of national security but rather to protect the lives of strangers abroad". ${ }^{5}$ In other words, public opinion matters tremendously for the decision-makers when deciding to intervene for humanitarian reasons.

The discussion has, so far, been unidirectional: political decision-makers take public opinion into account in their choices due to electoral prospects. Humanitarian interventions have high risks and low pay-offs in terms of public opinion, which makes political decision-makers reluctant. Yet public opinion is, of course, not only an exogenous variable. It is also elite-driven. Decision-makers actively try to affect the opinion of the public (e.g. Zaller 1992, 1994). Much of what politicians indeed do is trying to convince the public of their policies. Importantly, decision-makers have an informational surplus over the public concerning the anticipated cost and benefit of intervention (e.g. Downs and Rocke 1994). As such they can manipulate public opinion by presenting rosy or pale scenarios thereby furthering private interests. In other words, it is difficult a priori to establish directionality between public opinion and the foreign policy choices of decision-makers (Baum and Potter 2008).

In the interaction between public opinion and political decision-makers, news media are an intervening variable. First and foremost, news media are a transmission belt for public opinion to reach decision-makers and for decision-makers to affect public opinion. News media clearly need decision-makers as content providers and the broader public as their consumer base, which means that they have to carry out a careful balancing act. News media, however, also have agency in shaping both public opinion and foreign policy (e.g. Page, Shapiro and Dempsey 1987; Jordan and Page 1992; Entman 2004; Perla 2011). Essentially there exists thus a triangular relationship between public opinion, new media, and political-decision makers (Baum and Potter 2008).

Because directionality is so difficult to establish, the remainder of this article will not try to identify a casual path leading from public opinion, through the media and the political process, to the eventual foreign policy choices of decision-makers, which constitutes the ultimate dependent variable. ${ }^{6}$ Instead the empirical analysis will zoom in on news media in France and Germany and how they reported the arguments over intervention in Libya. It will show that the timing and the contents of the debate in news media differed in both countries. Assuming that news media indeed

The next two paragraphs of this article follow to a large extent their argument.

4 Jentleson (1992) distinguishes between force used to coerce restraint on an adversary and force used to influence or impose internal political change. The former is a much more narrow definition of national interest.

5 Important is to refer, in this regard, also to Prospect Theory (e.g. Kahneman and Tversky 1979). As politicians are risk-averse, they may still decide against humanitarian intervention even if the odds are that it yields benefits.

6 Because of space limitations, this article does not expand on the political process as an intervening variable. It is clear that the political colour of the government may affect its choice concerning intervention. In the case of Libya, both France and Germany had a centre-right government consisting of parties affiliated with the pan-European centre-right European People's Party. The exception was the German foreign minister. As this article will show, however, the difference between France and Germany were much more fundamental than the political colour of Westerwelle. 
'matter' as a transmission belt and as a shaper of public opinion and foreign policy, these differences in the domestic debate are important and may well help to explain why France and Germany made diverging choices.

\section{FRENCH AND GERMAN FOREIGN POLICY}

Much of the literature on the relations between public opinion and foreign policy is empirically inspired by case of the United States. Therefore, before going to the case of Libya, it is worthwhile to provide some context concerning the French and German foreign policy traditions with respect to intervention. To begin with France, it is difficult to overlook its active role as former colonial power in the Magreb and sub-Saharan Africa. With military bases in various African countries, Paris being the preferred place of residence of former African heads of state, and the Élysée Palace having a dedicated Africa cell, French contacts with the former colonies are rather intensive. France has also not hesitated to intervene (militarily) in the domestic politics of its former colonies ('Françafrique'). Its military actions in Ivory Coast in 2011 and Chad in 2008 are two recent well-known examples.

During the Fifth Republic, French Presidents and his private office have been at the centre of foreign policy regularly bypassing the foreign ministry. ${ }^{7}$ Much of the precedent was set by Charles de Gaulle, who put the concepts of 'independence' and 'grandeur' at the heart of his international agenda (Drake 2011). While French presidents are still judged on a Gaullist scale, there has been a remarkable continuity in foreign policy, including during the terms of Mitterrand (Moisi 1988) and arguably Sarkozy as well (Grossman 2010; Fortmann, Haglund and von Hlatky 2010). As a result of its ambiguous relationship with NATO, France had also to provide for itself. In addition to the force de frappe (which guaranteed independence and symbolised grandeur), this meant maintaining expeditionary forces that could be deployed to protect national interests oversees, particularly in Africa.

French foreign policy activism in Africa is a symbol for its interest to be of international importance, oftentimes no longer as a singular player but rather as a leader in international organisations such as NATO, the EU and the UN (Rowdybush and Chamorel 2011; Charillon and Wong 2011). The particular interest in Françafrique and the Magreb derives from its long-term investments, influence and economic relations with these countries as part of its colonial past and its particular interests in the region. Due to its historical ties with Africa, France recognises that its activism there is the most influential it can exercise on the international stage. ${ }^{8}$ Through active involvement in conflict resolution, France tries to strengthen its political ties with the US, show its possibility to use hard power, and increase the importance of Europe as a global player in the world (ibid).

By considering itself as a great power, France typically also feels a sense of obligation in international affairs. According to the UN Charter, the Security Council has "primary responsibility for the maintenance of international peace and security" (article 24(1)). As a permanent member, France uses these obligations whenever it suits its interests, including in the EU to keep Brussels bureaucrats away from UN security affairs. The primacy of the Security Council also gives France the 'right' not to consult too much and share information with EU allies, including Germany (e.g. de la Serre 1996). The international obligations go, however, beyond self-interest. In his inaugural speech, Mitterrand noted on foreign policy that "a great nation should entertain only noble projects and that France should 'enlighten humanity's progress"' (Moisi 1981: 347). The right to intervene in third states, whether through the UN or not, is part of this story.

The situation is rather different in Germany, where historical experience informs to a large extent foreign policy. Particularly, the baggage of the world wars has made Germany conscience of

7 This continues today as Kouchner experienced under Sarkozy. There are, of course, exceptions. Juppé was a powerful foreign minister (2011-2012).

8 French foreign policy has, of course, also evolved gradually as is evident from the 2008 White Paper on Defence, the return to NATO, and the opening of a military base outside Africa in the United Arab Emirates. 
its sensitive position in the international system. In accordance, it has followed a non-militaristic approach to foreign policy. It has put an emphasis on soft-power and (economic) diplomacy (e.g. Rummel 1996). Since the end of the Cold War, this conduct has been challenged by the growth in international peacekeeping and peace enforcement operations, for which Germany has been asked to make a contribution (Dettke 2009). While Germany has recently sent soldiers to operations in the Western Balkans and Afghanistan, this has remained subject of domestic debate (e.g. Maull 1995, 2000; Lantis 2002; Simms 2003; Noetzel and Schreer 2008; Miskommen 2009).

What is also important is Germany's attachment to multilateralism, which often presents a convenient cover of its actions. In the context of European integration, multilateralism was a means for example to regain legitimacy on the international stage (e.g. Rummel 1996; Daehnhardt 2011). Germany has been a strong supporter of NATO and the UN as well. It has also actively campaigned (so far unsuccessfully) for a permanent seat on the Security Council. While the Security Council in German eyes holds the ultimate legitimacy when it comes to humanitarian interventions, it is worth noting that Germany joined the NATO campaign over Kosovo in 1999, despite the lack of a resolution. In 2011, however, when Germany was a non-permanent member, it repeatedly noted the responsibility of Security Council in the implementation of resolutions. Abstaining from voting on Libya provided an excuse, from the German perspective, to not engage militarily.

The preferences concerning intervention and the use of force differ thus rather significantly in France and Germany. The same goes for relations with the Southern Mediterranean. Whereas France as a former colonial power feels a special bond with the Maghreb, Germany's relations are mostly economic and rather limited. This has resulted in strong debates within the European Union. At least since the Barcelona Declaration of 1995, France has tried to upload its policy towards the Mediterranean (also, of course, as quid pro quo for the possible eastern enlargement). Germany has instead tried to keep financial contributions to the Southern Mediterranean as limited as possible. In the Arab Spring, France has felt a responsibility, whereas Germany has been mostly interested in its own purse.

Finally, it is interesting to say something on the role of public opinion and foreign policymaking in France and Germany. French public opinion is still driven by the ideals of independence and grandeur. Helen Drake (2011: 199) argues that "these ideals still enjoy rhetorical support from across the political spectrum in France, and are as uncontroversial as they are ambiguous and ambitious". Moreover, since French Presidents are directly elected by popular vote and as foreign policy is considered the domaine réservé of the head of state, Presidents hold considerable authority in the eyes of the French public concerning foreign policy decisions. As a result "by and large [foreign policy is] a matter of public and political consensus" (ibid.: 200). That Bernard-Henri Lévy and Sarkozy held the same views on Libya could only happen in the realm of foreign policy.

On the contrary, German public opinion has regularly opposed key decisions taken by the government concerning foreign and security policy (e.g. protests against nuclear armament) (see Davis 2012). Yet typically once the decision is taken, public opinion rallies around the flag and supports the government (Tuschhoff 2005). Contrary to presidential France, public opinion in the German coalition-building democracy tends to be more fragmented. One reason is a higher number of political parties, leading to more variety in opinions on different policy issues and the need to find consensus between the governing parties (Risse-Kappen 1991; Lijphart 1999).

\section{NEWS MEDIA ON LIBYA: OVERVIEW}

After having discussed French and German foreign policy as well as how public opinion, the media and foreign policy-decision makers interact, it is now time for the empirical analysis. In order to analyse news media in France and Germany, this article relies upon newspaper articles. Needless to say, newspapers are only part of the media. They only provide a reflection of a part of the public debate in France and Germany. Newspapers are nonetheless one of the most diverse media. They include commentaries, opinion pages and polls, statements of various officials, etcetera. They thus 
give a rather comprehensive overview of the national debate. Finally, newspapers supply excellent data for academic analysis, which makes them a significant source.

\begin{tabular}{|l|l|}
\hline Date & Event \\
\hline 15 February & Start uprisings Libya \\
\hline 22 February & Gaddafi television appearance proclaiming brutal advancement \\
\hline 24 February & International community becomes active \\
\hline 26 February & $\begin{array}{l}\text { UN Security Council imposes sanctions and refers the case of Libya to the } \\
\text { International Criminal Court (Resolution 1970) }\end{array}$ \\
\hline 7 March & Gulf states endorse no-fly zone \\
\hline 10 March & France recognises Benghazi rebels as legitimate government of Libya \\
\hline 12 March & Arab League endorses no-fly zone \\
\hline 16 March & Gaddafi forces are closing in on Benghazi \\
\hline 17 March & $\begin{array}{l}\text { UN Security Council authorises no-fly zone and to "take all necessary } \\
\text { measures ... to protect civilians and civilian populated areas under threat of } \\
\text { attack in [Libya], including Benghazi" (Resolution 1973, para 4). }\end{array}$ \\
\hline 19 March & France starts air campaign against Gaddafi forces \\
\hline 31 March & NATO takes over command Operation Unified Protector \\
\hline 20 October & Death of Gaddafi \\
\hline Table 1. Chronology of events in Libya in 2011 \\
\hline
\end{tabular}

This article analyses a total of four sources, namely two French (Le Figaro and Le Monde) and two German (Die Welt and Die Süddeutsche Zeitung) newspapers. ${ }^{9}$ These are newspapers from different sides of the political spectrum and extensively cover international affairs. ${ }^{10}$ In order to get a better idea of news media in the crucial weeks around the adoption of Security Council Resolution 1973 on 17 March 2011, the selected time period in this article ranges from Sunday 13 February to Saturday 2 April 2011. As such, this article includes newspaper reporting from the very beginning of the uprisings in Libya until the moment that NATO took over the military operation led by France, the United Kingdom and the United States (see Table 1). This was the most contentious period in terms of the foreign policy divergence between France and Germany and the period in which the most important choices were made. All articles that include the word 'Libya' ('Libye'; 'Libyen') were initially collected, from which only those articles were manually selected that specifically addressed arguments on intervention. ${ }^{11}$ In total, there were 192 articles for France and 142 articles for Germany. This includes news reporting, analytical and opinion articles.

Graph 1 provides an initial overview of the number of newspaper articles per week for France (grey line) and Germany (black line). It also depicts the development of newspaper output in the respective countries. One can draw several interesting conclusions from this descriptive graph. First, the number of newspaper articles peak around the time of the two UN Security Council Resolutions. In three of the four cases, the peak is actually before the adoption of the resolutions. Although the sequence hints towards causality (news media influencing decision makers), it does not actually prove it. The peak before the adoption of both resolutions can, after all, also reflect strong public statements by politicians to create momentum to reach a resolution.

9 Die Frankfurter Allgemeine is not available through LexisNexis, which is a major database of newspaper articles.

10 These are also the newspapers typically used in EU and CFSP studies.

11 For example, French articles on the 'failure' of German foreign policy or German articles about the actions of foreign minister Westerwelle were excluded from the dataset. Such articles do not tell anything about the arguments made concerning the topic of intervention. 


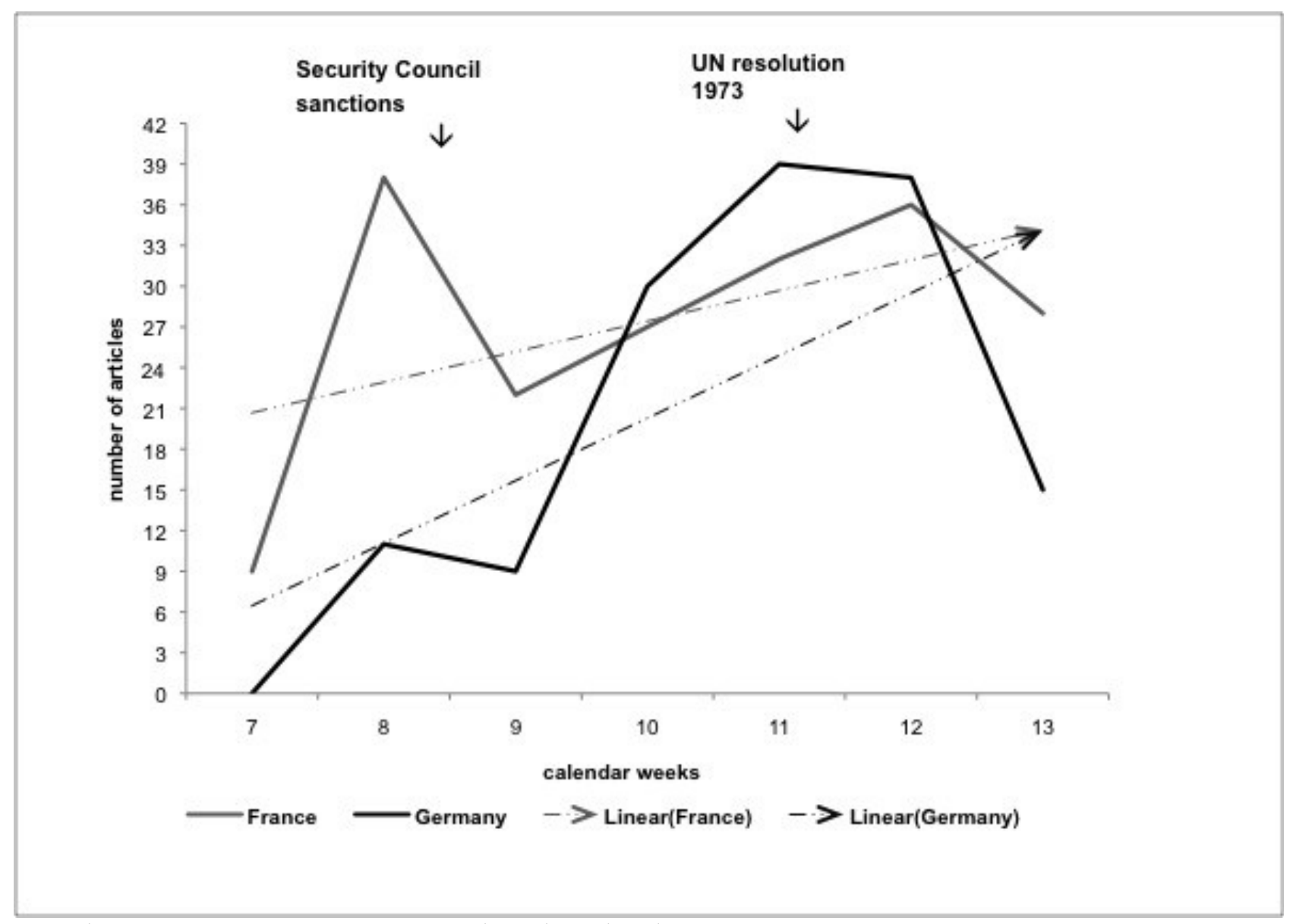

Graph 1: Newspaper output per week and its development over time

A second obvious conclusion is the significant discrepancy between France and Germany in terms of public opinion. The newspapers in Germany only started to wake up to the issues of Libya about one-and-a-half week before the actual decision was taken. In the first three weeks of the period under analysis, the two German newspapers published less than an article a day on average about Libya. In France, the amount of newspaper articles in the early period of the Libyan crisis was much higher. This discrepancy between France and Germany may have had consequences in terms of the decision-making. Given that there was initially so little press on Libya in Germany, it is not unreasonable to assume that German foreign policy decision-makers also paid less attention to the issue and had eventually much less time to formulate a reaction.

Following the selection of articles, they have been manually coded pro/neutral/against an international intervention in Libya. In terms of operationalisation, it is necessary to first understand what is meant by 'intervention'. In this article, it is defined as an intention of concrete action going beyond political dialogue. The context varied over the seven weeks of analysis. In the beginning, interventions were mainly about economic sanctions and only later about the establishment of a nofly zone and military intervention. For the coding, the first indicators were the titles and the first and last paragraph of each article. They usually were the most indicative of the orientation. Further, we counted quotes as indicators. In right-leaning Le Figaro, for example, Foreign Minister Alain Juppé was very frequently quoted in favour of intervention, while voices against were given little space.

Graph 2 shows the development of the orientation of news media concerning the intervention in Libya per week. To start with France, there exists a strong increasing trend in favour of intervention in the run up to Resolution 1973 in week 11. During the first weeks of the analysis, the majority of newspaper articles displayed a neutral tone towards intervention. As the decision came closer, the contents of newspaper articles incrementally became pro-intervention (with as much as $2 / 3$ of the articles in weeks 11 and 12). This fits well with a linear decision-making process 
during which different arguments are being considered. People make up their mind, and take a decision at the end of the process. What is also notable for France is that the number of articles with a majority of contra-arguments remained small during the whole period (between 10-23\%).

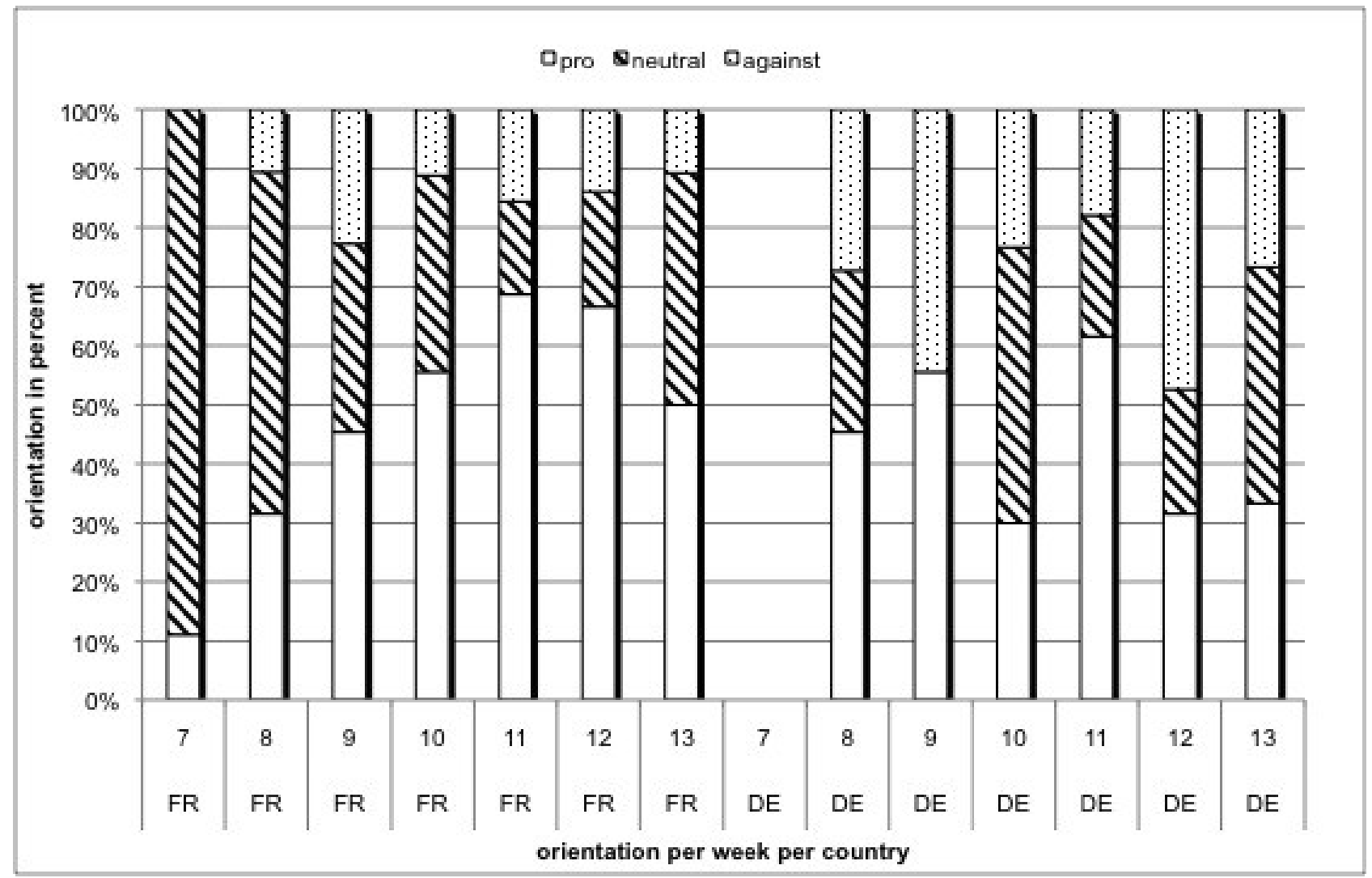

Graph 2: Orientation towards intervention of newspapers articles over time

If we turn to Germany, it is much more difficult to identify patterns. Take for example weeks 10-12, during which most articles were published. In week 10, articles were neutral towards intervention $(47 \%)$. One week later, a large majority of newspaper articles presented arguments in favour of an intervention (62\%). Finally, in week 12, after the Resolution was passed, most articles were against intervention (47\%). If anything, the orientation of German news media was thus much more erratic than in France. What is more, the number of newspaper articles with a majority of contraintervention arguments (18-47\%) was considerably higher than in France. Thus while there were no clear trends in German news media, one can still conclude that news media were less eager to start a Libyan adventure.

To come to a conclusion on the overall trends in news media, it has been shown that the French newspapers played an active role concerning the discussions on intervention in Libya. From the very start of the riots in Benghazi, French newspapers discussed the possibilities of intervention and became increasingly pro-interventionist along the way. The German press, on the other hand, did not play an active role during the first weeks, increasing its output essentially only in weeks 1012. The orientation towards intervention was furthermore fragmented, showing no clear trend. As noted before, one has to be cautious in terms of the causality between news media and the actions by foreign policy-makers. It is not possible from these data to automatically conclude that policymakers followed news media. What is clear is that news media was completely in line with eventual outcomes in both countries.

\section{NEWS MEDIA ON LIBYA: THE ARGUMENTS}

The previous section has provided an overall overview of news media on Libya in France and 
Germany. It is now time for a deeper and more thorough understanding of the discussions in the national newspapers. After having previously examined the overall proportion of pro/neutral/against articles, the remainder of this article is interested in the kinds of arguments that were brought forward. Which arguments were used in France and Germany and did they develop over time?

The starting point is to analyse the sorts of arguments that were made in the French and German press. Within the 334 newspaper articles, eleven significant arguments pro- or contraintervention can be identified. ${ }^{12}$ After having identified these eleven arguments, the next step is to determine whether they are equally present in the French and German press. For an argument to be 'present' in the respective countries, it has to be mentioned in at least three different articles. Later on this article will get back to the question of which arguments were extraordinarily dominant, but first it is interesting to have a look at the overall results - the arguments that were at least mentioned three times - which are summarised in table 2.

\begin{tabular}{|c|c|c|}
\hline & France & Germany \\
\hline \multicolumn{3}{|l|}{ Pro-intervention } \\
\hline Support rebels & $\mathrm{x}$ & $\mathrm{x}$ \\
\hline Responsibility to Protect & $\mathrm{x}$ & $\mathrm{x}$ \\
\hline Economic reasons (e.g. oil) & $\mathrm{x}$ & $\mathrm{x}$ \\
\hline Human rights & $\mathrm{x}$ & $\mathrm{x}$ \\
\hline Prevention of terrorism & $\mathrm{x}$ & $\mathrm{x}$ \\
\hline Special relations with region & $\mathrm{x}$ & \\
\hline \multicolumn{3}{|l|}{ Contra-intervention } \\
\hline Rebels have no legitimacy & & $\mathrm{x}$ \\
\hline Long-term military commitment & $\mathrm{x}$ & $\mathrm{x}$ \\
\hline Sovereignty of Libya & & $\mathrm{x}$ \\
\hline Need for regional solution & & $\mathrm{x}$ \\
\hline Other means (e.g. political dialogue and sanctions) & $\mathrm{x}$ & $\mathrm{x}$ \\
\hline
\end{tabular}

Table 2. Arguments used pro-/contra-intervention in national press.

Unsurprisingly, these results are to a large degree in line with the results presented in the previous section. There exists a significant difference between France and Germany in terms of the balance between pro- and contra-intervention arguments. While the arguments in favour of intervention were almost the same in France and Germany, much more arguments against intervention were used in Germany. This, needless to say, is in line with the eventual foreign policy outcomes. What is perhaps somewhat surprising is that the debate in Germany was more comprehensive. Given that the debate in the German press was much shorter in terms of time (only in weeks 10-12), this is somewhat counterintuitive.

More importantly, however, the comprehensiveness of the debate in Germany is evidence that decision-making may not have been as erratic as what has been suggested above. Indeed, the great number of arguments that deal with issues of legitimacy, national sovereignty and the need for a regional solution point to the historical non-interventionist tradition in German post-war foreign policy. On the basis of this evidence it can be argued that decision-makers, when Libya came on their agenda, fell back to traditional ways of operating. In the absence of full legitimacy and clear prospects of success, Germany remained wary of using military means for foreign policy ends that

12 A significant argument is an argument that was used at least in four different newspaper articles and that was clearly either pro- or contra-intervention. 
went beyond national self-interest.

It is, however, not only interesting to note whether an argument was put forward or not, but also to consider at which point in time it was published and how often it appeared. As will be shown below, different arguments were dominant at different points in time. During the seven weeks, which have been analysed in this article, the content of the discourse changed considerably. The selection of arguments in table 2 can help to illustrate this development over time. While the table only shows whether an argument was used in France or Germany, it makes sense to put the points that were raised in the public discussion in chronological order. That way, it can be detected in how far news media and international power relations reacted towards each other.

Following the riots in Benghazi on 15 February 2011, public debate in France concerning intervention started right away. The emphasis was on human rights and evolved around altruistic concepts such as 'support the democratic movement' and 'responsibility to protect' (R2P). The moment that the international community got an idea of how brutally the Gaddafi regime reacted to the uprisings, supporting the democratic movement in Libya became the main concern in France. At that stage, the emphasis was still on a political reform process (Le Monde 2011a). As demonstrated above, the German newspapers did not discuss intervention in Libya in the first week. And when they slowly started to engage in the debate, the question of intervention was met with scepticism. The eleven articles from week 8 name different possible actors that should be in charge of interfering (e.g. the United Nations, the Arab region, the EU). Germany itself tried to stay out, as it was still considering whether it would be right to support the rebels. France did not share these concerns. News media started calling the situation a 'civil war' by week 8 , thereby underlining the necessity to act in support of the Libyan citizens. Besides, economic reasons also played a role in the French debate. As the development of the oil price is closely linked to the stability of the region, France, which has close economic ties with Libya as a former colonial power, was worried about losing influence in trade relations.

R2P, with an emphasis on outside military intervention, started to gain weight in the French press by the end of February. Mere support for the democratic movement was no longer enough in the light of Gaddafi's violation of human rights. This indicates a development from moderate means of intervention towards military means, including a no-fly zone. Consider the strong words that Le Monde quoted from Alain Juppé's blog (2011b):

Everyone knows what is approaching; yet they prefer to look the other way. Once the massacre has happened, there will be time for words of condemnation and regret. Rwanda, Bosnia: and no lesson learnt. What is the benefit of advocating an international community if it is continuously every man for himself? For once, let's admit, France - together with Great Britain - did not hesitate to defend a firm line. ${ }^{13}$

In Germany, there was a strong preference for 'finding a solution in the region' and respecting the 'national sovereignty of Libya'. Arguably, these preferences masquerade the fact that Germany was not eager to get involved militarily in any potentially long-lasting conflict, but they also resonate with the non-interventionist tradition. An interesting statement, in this respect, came from the German foreign minister, Guido Westerwelle, who noted that "[e]ven the semblance of Western interference weakens those who fight courageously for freedom" (Süddeutsche Zeitung 2011a). ${ }^{14}$ Overall, the dispersion between pro and contra arguments was relatively equal except during the week of Resolution 1973, when more than $60 \%$ of the articles supported intervention. Still, even when the support for the Libyan opposition was at its height, German news media did not abolish its suspicion towards military engagement and clearly stated that they did not want to become involved as a warring party. The no-fly zone was the preferred strategy, as it holds little risk for

13 "Chacun sait ce qui se prépare, mais préfère regarder ailleurs. Une fois le massacre perpétré, il sera toujours temps d'avoir des paroles de condamnation et de regret. Rwanda, Bosnie : rien ne sert de leçon. A quoi cela sert-il de parler d'une communauté internationale si c'est pour prôner en permanence le chacun pour soi? Pour une fois, reconnaissons-le, la France - avec la Grande Bretagne - n'a pas hésité à défendre une ligne de fermeté"

14 "schon der Anschein westlicher Einmischung schwächt diejenigen, die mutig für die Freiheit kämpfen" 
casualties. In week 12, the head of the foreign affairs working group of the German Bundestag, Ruprecht Polenz, expressed that "solidarity with international alliance is possible without standing in the first line of the battle field in every mission" (Süddeutsche Zeitung 2011b). ${ }^{15}$

It is also interesting to see that after the German abstention from voting on Resolution 1973, Germany rallied around the flag. ${ }^{16}$ Die Welt (2011a), for example, noted on German public opinion that "[a]ccording to [a] ... survey ... 62 percent think that the military operation against the Libyan dictator is correct. At the same time, 65 percent do not want the 'Bundeswehr' to be involved in actual attacks". ${ }^{17}$ Such arguments against German military involvement remained dominant in the German press.

This section has shown that the arguments that were raised in the French and German press differed considerably. The longer the revolution prevailed, the more the arguments urged for an intervention. However, only the French decision-makers could agree on taking action. In Germany, a heated debate considering both sides emerged, without determining a coherent reaction. Furthermore, there is a clear causal connection between the developments of the uprisings in Libya and the tone of the arguments. The public discussion intensified over time and was especially strong during the Security Council debate on sanctions in Week 8 and the eventual Resolution 1973.

\section{CONCLUSION}

This article started off by pointing at the lack of political consensus in the EU concerning the humanitarian intervention in Libya. France and the United Kingdom took a diplomatic leadership role in the Security Council and were at the forefront of the military campaign. Germany abstained from voting on Resolution 1973 thereby splitting Europe at the United Nations on this important dossier. While the case of Libya is relevant in itself, it was clearly not the first time that the EU member states disagreed on a key foreign policy issue. In the last decade, there have been political stand-offs on inter alia Iraq, Kosovo, and the Middle-East Peace Process. It is therefore important to get a better understanding why major EU member states diverge on these topics of high politics. The article points, in the case of Libya at least, towards the relevance of domestic politics and news media.

The mix-methods approach employed in this article has shown that the timing, balance and content of the debates in France and Germany differed in the case of Libya. First, Libya became topic of debate in Germany much later than in France. The speed with which events unfolded took the German public and decision makers by surprise. It is thus conceivable that German decision makers had more trouble to formulate an adequate reaction. ${ }^{18}$ Second, while French news media became increasingly in favour of intervention, the arguments in German newspapers changed from week-to-week. This gave German decision-makers little guidance. Finally, despite the much shorter debate in Germany, it was more comprehensive than in France, including arguments concerning the legitimacy of the intervention. This fits in well with the German foreign policy tradition.

This article has not attempted to explicitly establish causality between public opinion and news media, on the one hand, and foreign policy choices, on the other. It has clearly shown, however, that news reporting and foreign policy choices in France and Germany were in line. This confirms the relevance of domestic politics when it comes to humanitarian interventions. That having been said, the cost-benefit calculations of decision-makers and their risk aversion are perhaps not as straightforward as the literature suggests. Much of the theory has been informed by the United States' context and the American experiences in Somalia and former Yugoslavia during

15 "Man kann Bündnissolidarität zeigen, ohne bei jedem Einsatz an vorderster Front mitzumachen"

16 In spite of several key figures, such as Joschka Fischer, who talked about a historic mistake.

17 "Nach einer Emnid-Umfrage im Auftrag von Bild am Sonntag finden 62 Prozent den Militäreinsatz gegen den libyschen Diktator richtig. Gleichzeitig befürworteten 65 Prozent, dass sich die Bundeswehr nicht an den Angriffen beteiligt"

18 See Miskimmon (2012) for an alternative story. He argues that the German abstention was an explicit choice based on a cost-benefit analysis. 
the 1990s. The results of this article suggests that the French and German domestic contexts, which differ from the American one, also affect the extent to which news media informs the choices of decision-makers.

While the German vote in the Security Council seemed to confirm the expectations of the literature (risk aversion and no clear national interest), the presence of historical legacy and the arguments concerning the legitimacy of intervention made Germany even less inclined than the United States to engage in the military operation. ${ }^{19}$ Similarly, while French decision-makers were certainly supported by the public, a humanitarian intervention in an election year was still a major risk. ${ }^{20}$ When it comes to France, it is thus also necessary to consider the specific French domestic context with its presidential system and the presidential prerogatives. In addition, one has to point at the colonial background. For the theory of domestic politics and humanitarian interventions, it is thus important to go beyond the case of the United States and be informed by the domestic context of other states as well.

\section{ACKNOWLEDGEMENTS}

The research leading to these results has received funding from the People Programme (Marie Curie Actions) of the European Union's Seventh Framework Programme (FP7/2007-2013) under REA grant agreement $\mathrm{n}^{\circ} 298081$.

\section{REFERENCES}

Allison, G. (1971) Essence of decision: Explaining the Cuban missile crisis, Boston: Little Brown.

Almond, G. (1950) The American people and foreign policy, New York: Harcourt Brace.

Barry, B. (2011) 'Libya's Lessons', Survival 53(5): 5-14.

Baum, M. (2004) 'How Public Opinion Constrains the Use of Force: The Case of Operation Restore Hope', Presidential Studies Quarterly 34(2): 187-226.

Baum, M. and Ph. Potter (2008) 'The Relationships Between Mass Media, Public Opinion, and Foreign Policy: Toward a Theoretical Synthesis', Annual Review of Political Science 11: 39-65.

Beach, D. (2012) Analyzing Foreign Policy, Basingstoke: Palgrave Macmillan.

Benitez, J. (2011) 'National Composition of NATO Strike Sorties in Libya', Atlantic Council blog, 22 August, online available at: http://www.acus.org/natosource/national-composition-nato-strikesorties-libya (accessed 23 October 2012).

Daalder, I. and J. Stavridis (2012) 'NATO's Victory in Libya', Foreign Affairs 91(2): 2-7.

Daehnhardt, P. (2011) 'Germany in the European Union', in R. Wong and C. Hill (eds) National and European Foreign Policies: Towards Europeanization (pp. 19-34), London: Routledge.

19 While the United States has not been the subject of this article, the reaction of its decision-makers towards the intervention in Libya was a textbook example of the cost-benefit analyses that the literature expects. President Obama was initially very hesitant to intervene. Only after the situation escalated and following pressure from people such as Susan Rice (US Representative to UN) and Samantha Powers (National Security Council), Obama decided to support the intervention. Even then he did not want to be seen as taking the lead.

20 Arguably the military campaign took longer than France had expected but it remained a major political gamble for the incumbent President Sarkozy. 
Davis, W. (2012) 'The public opinion? Foreign policy paradox in Germany: integrating domestic and international levels of analysis conditionally', European Security 21(3): 347-369.

Drake, H. (2011) Contemporary France, Basingstoke: Palgrave Macmillan.

Dettke, D. (2009) Germany Says 'No': The Iraq War and the Future of German Foreign and Security Policy, Washington D.C.Woodrow Wilson Center Press.

Die Welt (2011a) 'Regierung rechtfertigt den deutschen Sonderweg', 21/03/2011.

Donnelly, J. (1993) 'Human Rights, Humanitarian Crisis, and Humanitarian Intervention', International Journal 48(4): 607-640.

Downs, G. and D. Rocke (1994) 'Conflict, agency, and gambling for resurrection: The principalagent problem goes to war', American Journal of Political Science 38(2): 362-380.

Eichenberg, R. (2005) 'Victory Has Many Friends: U.S. Public Opinion and the Use of Military Force, 1981-2005', International Security 30(1): 140-177.

Entman, R. (2004) Projections of power: Framing news, public opinion, and US foreign policy, Chicago: The University of Chicago Press.

Fearon, J. (1998) 'Domestic politics, foreign policy, and theories of international relations', Annual Review of Political Science 1: 289-313.

Fortmann D., Haglund, D. \& von Hlatky, S. (eds) (2010) 'France's return to NATO: implications for transatlantic relations', European Security 19(1): 1:142.

Gates, R. (2011) 'The Security and Defense Agenda (Future of NATO)', Brussels, 10 June, online available at: http://www.defense.gov/speeches/speech.aspx?speechid=1581.

Grossman, E. (ed.) (2010) 'The New 'Special Relationship'? Us- Relations in the Age of Sarkozy', European Political Science 9(2): 149-222.

Hallams, E. and B. Schreer (2012) 'Towards a 'post-American' alliance? NATO burden-sharing after Libya', International Affairs 88(2): 313-327.

Hildebrandt et al. (2012) 'The Domestic Politics of Humanitarian Intervention: Public Opinion, Partisanship, and Ideology', Foreign Policy Analysis, DOI: 10.1111/j.1743-8594.2012.00189.x.

Hill, C. (1993) 'The capability- expectations gap, or conceptualizing Europe's international role', Journal of Common Market Studies 31(3): 305-328.

Holsti, O. (1992) 'Public opinion and foreign policy: Challenges to the Almond-Lippmann Consensus Mershon Series: Research programs and debates', International Studies Quarterly 36(4): 439-466.

Holsti, O. (1996) Public opinion and American foreign policy, Ann Arbor: The University of Michigan Press.

Jentleson, B. (1992) 'The pretty prudent public: Post post-Vietnam American opinion on the use of 
military force', International Studies Quarterly 36(1): 49-73.

Jentleson, B. and R. Britton (1998) 'Still Pretty Prudent: Post-Cold War American Public Opinion on the Use of Military Force', Journal of Conflict Resolution 42(4): 395-417.

Jordan and Page (1992) 'Shaping foreign policy opinions: The Role of TV News', Journal of Conflict Resolution 36(2): 227-241.

Kahneman, D. and A. Tversky (1979) 'Prospect theory: An analysis of decision under risk', Econometrica 47(2): 263-292.

Kull, S. (1995) 'What the Public Knows that Washington Doesn't', Foreign Policy 101: 102-115.

Lantis, J. (2002) Strategic dilemmas and the evolution of German foreign policy since unification, Westpost: Praeger Publishers.

Le Monde (2011a) 'La communauté internationale doit revisiter sa politique', 18/02/2011.

Le Monde (2011b) 'Le dos tourné', 17/03/2011.

Lijphart, A. (1999) Patterns of Democracy: Government Forms and Performance in Thirty-six Countries, New Haven: Yale University Press.

Lippmann, W. (1955) Essays in Public Philosophy, Boston: Little, Brown.

Maull, H. (1995) 'Germany in the Yugoslav crisis', Survival 37(4): 99-130

Maull, H. (2000) 'German foreign policy, Post- Kosovo: Still a “civilian power?", Germany Politics 9(2): 1-24.

Milner, H. (1997) Interests, institutions, and information: Domestic politics and international relations, Princeton: Princeton University Press.

Miskimmon, A. (2009) 'Falling into line? Kosovo and the course of German foreign policy', International Affairs 85(3): 561-573.

Miskimmon, A. (2012) 'German Foreign Policy and the Libya Crisis', German Politics 21(4): 392410.

Moisi, D. (1981) 'Mitterrand's Foreign Policy: The Limits of Continuity', Foreign Affairs 60(2): 347-357.

Moisi, D. (1988) 'French Foreign Policy: The Challenge of Adaptation', Foreign Affairs 67(1): 151164.

Moravcsik, A. (1997) 'Taking preferences seriously: A liberal theory of international politics', International Organization 51(4): 513-553.

Müller, W. and K. Strom (1999) Policy, office, or votes?: how political parties in Western Europe make hard decisions, Cambridge: Cambridge University Press.

Noetzel, T. and B. Schreer (2008) 'All the way? The evolution of German military power', 
International Affairs 84(2): 211-221.

Page, B., R. Shapiro and G. Dempsey (1987) 'What moves public opinion?', The American Political Science Review 81(1): 23-44.

Perla, H. (2011) 'Explaining Public Support for the Use of Military Force: The Impact of Reference Point Framing and Prospective Decision Making', International Organization 65(1): 139-167.

Powlick, P. and A. Katz (1998) 'Defining the American public opinion/foreign policy nexus', Mershon International Studies Review 42(1): 29-61.

Putnam, R. (1988) 'Diplomacy and domestic politics: the logic of two-level games', International Organization 42(3): 427-460.

Risse-Kappen, T. (1991) 'Public opinion, domestic structure, and foreign policy in liberal democracies', World Politics 43(4): 479-512.

Rosenau, J. (1961) Public opinion and foreign policy: An operational formulation, New York: Random House.

Rosenau, J. (1967) The Domestic Sources of Foreign Policy, New York: The Free Press.

Rowdybush, B., Chamorel, P. (2011). 'Aspirations and Reality:French Foreign Policy and the 2012 Elections', The Washington Quarterly 35(1): 163-177.

Rummel, R. (1996) 'Germany's Role in the CFSP: 'Normalität' or 'Sonderweg'?' in C. Hill (ed.), The Actors in Europe's Foreign Policy (pp. 40-67), London: Routledge.

Serre, de la, F. (1996) 'France - The impact of François Mitterrand', in C. Hill (ed.), The Actors in Europe's Foreign Policy (pp. 19-39). London: Routledge.

Simms, B. (2003) 'From the Kohl to the Fischer Doctrine: Germany and the Wars of the Yugoslav Succession, 1991-1999', Germany History, 21(3): 393-414.

Sobel R. (2001) The Impact of Public Opinion on U.S. Foreign Policy Since Vietnam, Oxford: Oxford University Press.

Stimson, J. (2004) Tides of consent: How public opinion shapes American politics, Cambridge: Cambridge University Press.

Süddeutsche Zeitung (2011a) 'Gaddafis Herrschaft in Tripolis bröckelt', 26/02/2011

Toje, A. (2008) 'The Consensus-Expectations Gap: Explaining Europe's Ineffective Foreign Policy', Security Dialogue 39(1): 121-141.

Tuschhoff, C. (2005) Explaining the Multilateral Reflex: German Foreign Policy, 1949- 2002, Working Paper No. 12-05, American Institute for Contemporary German Studies.

Wong, R. (2011) 'France: Europeanization by default?', in R. Wong and C. Hill (eds) National and European Foreign Policies: Towards Europeanization (pp. 19-34), London: Routledge.

Zaller J. (1992) The Nature and Origins of Mass Opinion, Cambridge: Cambridge University Press. 
Zaller, J. (1994) 'Elite leadership of mass opinion: new evidence from the Gulf War', in L. Bennett and D. Paletz (eds) Taken by Storm: The Media, Public Opinion and U.S. Foreign Policy in the Gulf War (pp. 186-209), Chicago: The University Chicago Press 